ESSAY II

\title{
'La Escocesa': A fabric of images
}

\section{PLÁCIDO MUÑOZ MORÁN}

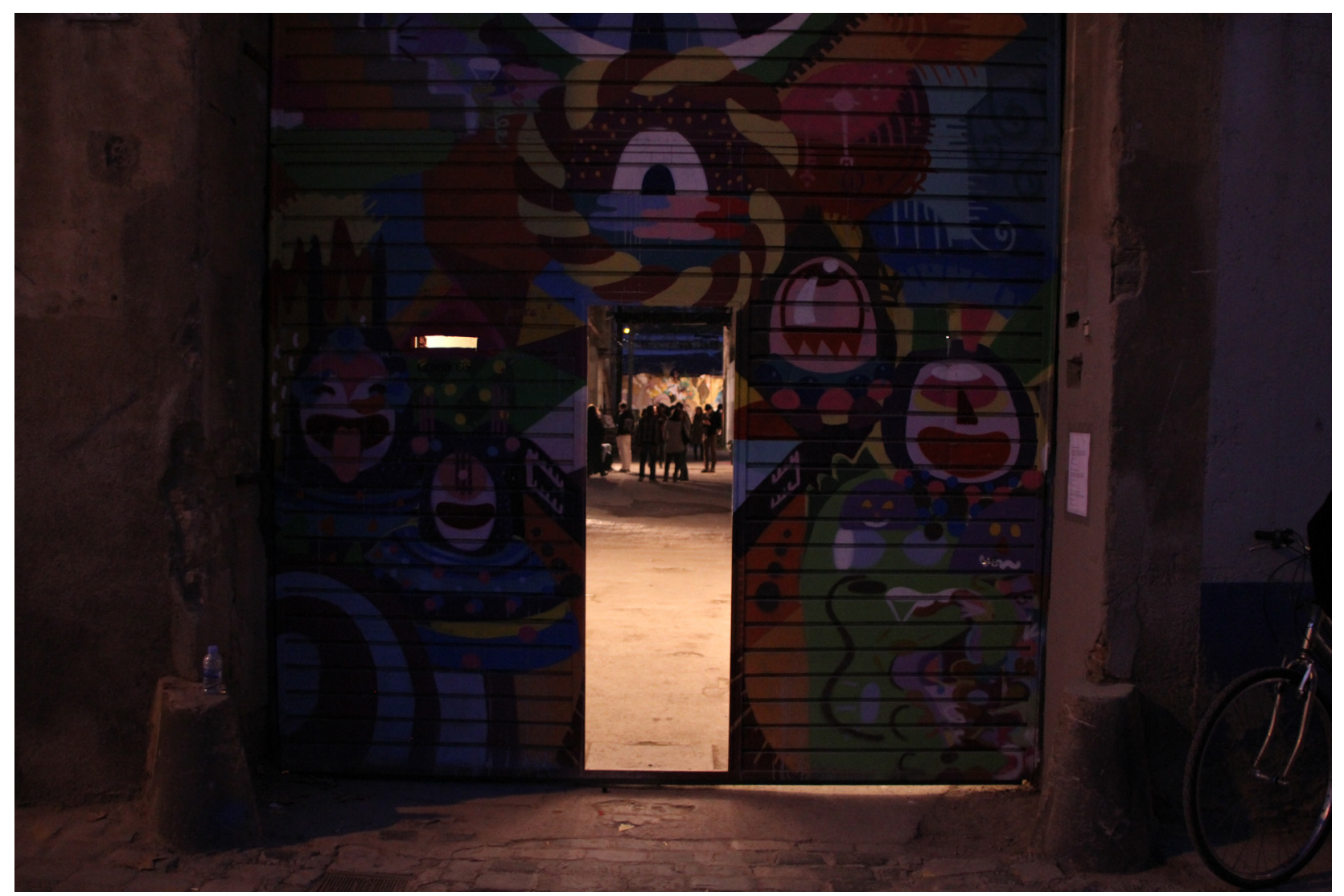

Main gate to 'La Escocesa'

All photos (C) Plácido Muñoz 


\title{
'La Escocesa': A fabric of images
}

\author{
PLÁCIDO MUÑOZ MORÁN
}

The banning of the practice of graffiti in public space since the approval of the civic regulation in 2006 restricted the production of graffiti artworks in Barcelona. It transformed and coerced the local graffiti and street art scene towards new forms of production and perception of the city. However, this transformation did not stop graffiti artists opening up dialogues through their works in public space and other contexts. Inspired by this dialogic nature of graffiti, in 'La Escocesa: A factory of images' I put in practice dialogic methodologies by sharing written research cases with the resident graffiti artists in the art centre. This allows me to gain an insight of how graffiti artists perceive and represent the city and its objects in contrast and comparison with researchers who think and write about similar issues. The following paper contains part of the conversations, debates, and reflections that we had.

\section{Introduction}

The explosion of graffiti and street art in Barcelona in the 1990s coincided with the transformation of the central district neighbourhood of 'El Raval'. The main aim of the city council through this urban project was to renew the 'urban texture' (Degen 2008) of this neighbourhood, transforming its reputation of marginality, drug abuse and prostitution. According to Degen (2008), '... the Raval's 'urban texture' was defined by a multi-layered, complex and diverse structure, which today still gives the impression of a chaotic unplanned space' (ibid: 80). The urban renewal of 'El Raval' triggered mass evictions, real estate speculation and the demolition of buildings. During this process of transformation, the number of abandoned buildings and empty construction sites in the neighbourhood grew. Such spaces became the perfect spots for the practice of graffiti and street art and it eventually favoured the creation of a recognised scene of this phenomenon in Barcelona. However, after the council passed a new civic ordinance in 2006, the central district of the city, once the sanctuary and main exhibition spot, became a graffiti and street art free zone. Here graffiti and street art interventions were criminalized and sanctioned with high penalties under the new regulation. This pushed graffiti artists to look for new spaces and alternative ways of producing their artworks in the city. Trying to understand and represent these changes of the graffiti and street art scene in Barcelona, I began research in social anthropology with visual media that I completed in 2015 at the University of Manchester. As part of that broader research this paper explores the practice of dialogic methodologies between anthropologists and graffiti artists to explore new ways for knowledge production and representation.

The participants in this paper were graffiti and street artists in the art centre of 'La Escocesa'. Most of these graffiti artists developed their graffiti and muralist skills in the 1990s. Today, their artworks are known internationally and appear in graffiti documentaries, and in various graffiti and street art magazines and books. Many of their murals and artworks are made in other cities, on canvas, or on the walls of 'La Escocesa' and its surroundings in the neighbourhood of Poble Nou in Barcelona.

\section{Writing on the city}

The cities created under the Spanish colonialism of Latin America were controlled by the so-called 'letrados', who used their writing skills and elite position to distribute and organize cities creating what Angel Rama (1996) defines as the 'lettered' cities. The 'letrados' planned the order and distribution of urban space, which were imposed upon the inhabitants (Rama 1996:1). In contrast, graffiti and street artists write and draw on the surfaces of the city fostering dialogues, which open up an incoherent multiplicity of discourses. I have incorporated this dialogic aspect into my research through the voices of the different participants in juxtaposition to my own. Drawing on Mikhail Bakhtin's (1981) approach to language as an instrument of contradictory worldviews, this piece is an attempt to represent the polyphonic and complex nature of the ethnographic research and fieldwork in the city and beyond. The use of dialogic strategies in ethnographic 
research is based not only on learning how other people communicate through verbal language, but also takes into account feelings, signs and other non-verbal ways of communication. The context of fieldwork is continually renegotiated (Clifford 1980) and the ethnographic task within is to not only record the 'indigenous' view of a shared life world, but also to reveal the interactive issues that appear in this relationship (Page 1988:165) between participants and ethnographers, as well as between their social and material worlds. Zosen, one of the graffiti artists in 'La Escocesa' once told me:

“... graffiti artists are able to read the city and write their own stories on its surfaces".

Thus, the distribution of the urban space for them is encoded within a sensory order that can be read and rewritten. Graffiti artists explore the labyrinth of streets reading the surfaces of the cities to create artworks as a way of rewriting the city in subversive and resistant forms against the established order. I propose to write my own story on the city and its elements exploring how the knowledge produced by anthropologist is perceived, interpreted and transformed within dialogues between graffiti artists and myself. These dialogic interactions produce spaces in between in which the lives and perceptions of anthropologists and graffiti artists are shared and transformed into written knowledge. To provide an account of this dialogic coming into being, the text is structured upon a differentiation between the voice of the graffiti artists, which appear in boxes, and my own voice, which is not.

\section{Walking in 'La Escocesa'}

Three outdoor corridors connected to a large patio formed the space for the graffiti murals. All of this space, together with three factory buildings is part of the art centre of 'La Escocesa'. The murals were painted on the outside walls that form the patio, the corridors, and the buildings of the former industrial complex. I walked into this scenario over its irregular floors formed by different usages of the building and comprising patches of cement and soil. My first impression was of an abandoned and old industrial complex with walls of different colours and textures. There were disused lifts, rusty pipes and electric wires visible on the walls. This is the space in which the murals appear as something between old and new, past and present and between processes of creation and destruction. There are old red bricks, cement with different layers of paint and doors and windows that suddenly take on new meanings and attention. Coming back to our walking route through 'La Escocesa' and walking within the main corridor we finally get to the large patio. It is here that the biggest murals are painted around a solitary, tall chimney in the middle of the patio, surrounded by rubble, vegetation, half demolished walls and bent construction irons but which probably, forty years ago, liberated the smoke of one of the factories.

I began my PhD fieldwork in 2011, the same year that I learned about 'La Escocesa' through the multidisciplinary artist, Jorge Rodriguez Gerada ${ }^{1}$. At the time, he was a resident artist in this art centre and I met him in his studio. He had been working on large-scale ephemeral charcoal drawings on public space walls as part of his 'Identity' series. In relation to this series, he explained to me that he only worked on certain surface walls that inspired him to create hyper realistic drawings using charcoal as a metaphor for the passing of time and the transformation of society and the city. His aim was to open up dialogs with the residents of the neighbourhoods where he created his works, making an analogy between the changeable and fragile character of his charcoal portraits and the idea of belonging and the memories of the people. This encounter with Jorge and his artworks was very inspiring for this research. The 'Identities' series enclosed multiple dialogues between the artist and the collaborators, between the artist and the city space with its surfaces and textures, as well as between the city space, the inhabitants, and the artworks in public space over time. I incorporated this dialogic dimension into my own research so as to share and contrast different perspectives on the city and its elements. During the first stage of my research, my conversations with Jorge opened up the possibility of dialogues with other artists in 'La Escocesa'. I shared with them some of the anthropology readings that I was using in my research. In this way, I wanted to foster reflexive dialogues about the transformation of the city and the ways in which graffiti and street art exist within it. It was this first experience of Jorge's work that marked my fieldwork and shaped my ethnographic work by encouraging me to engage in collaborations based on equality and 'practical experimentation' (Strohm 2012: 118). Later that

1 http://www.jorgerodriguezgerada.com/ 
same year, Jorge and his family moved away from Barcelona to the smaller city of Tudela in northern Spain, and I lost contact with him for the rest of my fieldwork. However, I kept visiting 'La Escocesa' and sharing ideas with artists, such as $\mathrm{Kafre}^{2}$, and Zosen ${ }^{3}$ who belonged to the renowned ONG graffiti crew, Ovejas Negras or "Black Sheep".

My encounters with the graffiti artists in 'La Escocesa' evolved from simple conversations and semi-structured interviews to dialogues and debates in which I used anthropology case studies to share with them my views about the city and its transformation. The following sections contain part of these dialogues intertwined with my theoretical analysis, images, and description of practices and places where these dialogues were performed.

\section{Imagining 'La Escocesa'}

The first of these encounters was with Zosen, the main organizer of the Murals Festival in 'La Escocesa', which I will discuss later in this paper. Zosen is considered one of the key figures of the graffiti scene in the city, and his visual language, according to the anthropologist Rafael Schacter (2013), embodies "a unique anarcho-primitivist aesthetic" (2013: 312). Thus Zosen's artworks are not only based on rich and vivid colours that take forms of native or tribal symbols but they are also charged with serious political intents and activism, which characterize the graffiti aesthetics of Barcelona (Schacter 2013:312). That same day I also met two other graffiti artists, Kenor ${ }^{4}$ and $\mathrm{H}_{101}{ }^{5}$, who shared a studio with Zosen in 'La Escocesa' and were part of the 'Collectivo A + B'. Kenor and H101 were working on a collaborative painting on canvas using colours from spray cans but applying them with a brush. We were sitting on a sofa and I explained to Zosen what my project was about. I told him how curious I was about 'La Escocesa' and its transformation into an art centre. I moved back in time to imagine the building as the textile and chemical factory it once was. At that time, I kept imagining and telling Zosen that the space was used by workers in their everyday production tasks; they transformed materials into commodities that were eventually sold in the market. Today the same space is used to produce art, organize exhibitions and workshops; and in the case of the 'Murals Festival', the buildings' walls were transformed into mural artworks by graffiti artists, which were then seen, appreciated, and photographed by the general public. The former life of the industrial factory was still visible in the structure of the building that formed 'La Escocesa' and I wondered if that influenced the work of the artists. I thought that if this factory building was conserved by the institutions as part of the local cultural patrimony and the workers' history and memory in the city, it also enclosed some sort of 'soul' ${ }^{6}$, which shaped the practice of the graffiti and street artists who imagined and produced their artworks within this space. After my imagined 'story', I was expecting Zosen to tell me how the history of 'La Escocesa' had shaped and conditioned his artworks. In contrast, he said:

“...I don't think so. We are, as graffiti artists, very adaptable artists; the space only conditions our work because it is there or it isn't. If you have more or less space and time you can end up developing your activity here, in the street or on a train when you have three minutes to paint...".

H101, who continued painting on a canvas, agreed with him:

"...the space only conditions our artworks physically. However, the fact that we spend so much time in 'La Escocesa', and here there are so many demolished buildings around that it is good for us because we have less restrictions and we like those kinds of surfaces and spaces so as to get inspired and explore different possibilities through our artworks. The material features of this landscape work harmonically with our artworks and are currently key elements to producing most of our murals in Barcelona".

2 http://lleonka.tumblr.com/

3 http://www.animalbanido.com/tofulines/

$4 \mathrm{http}: / /$ www.elkenor.com/

5 http://www.hcientouno.com/

6 Linked to Zukin's concept of authenticity developed in her book 'The Naked City' (2010) and based on the idea of

'origins': 'a human right, that is cultivated by longtime residence, use and habit' (2010:244). 

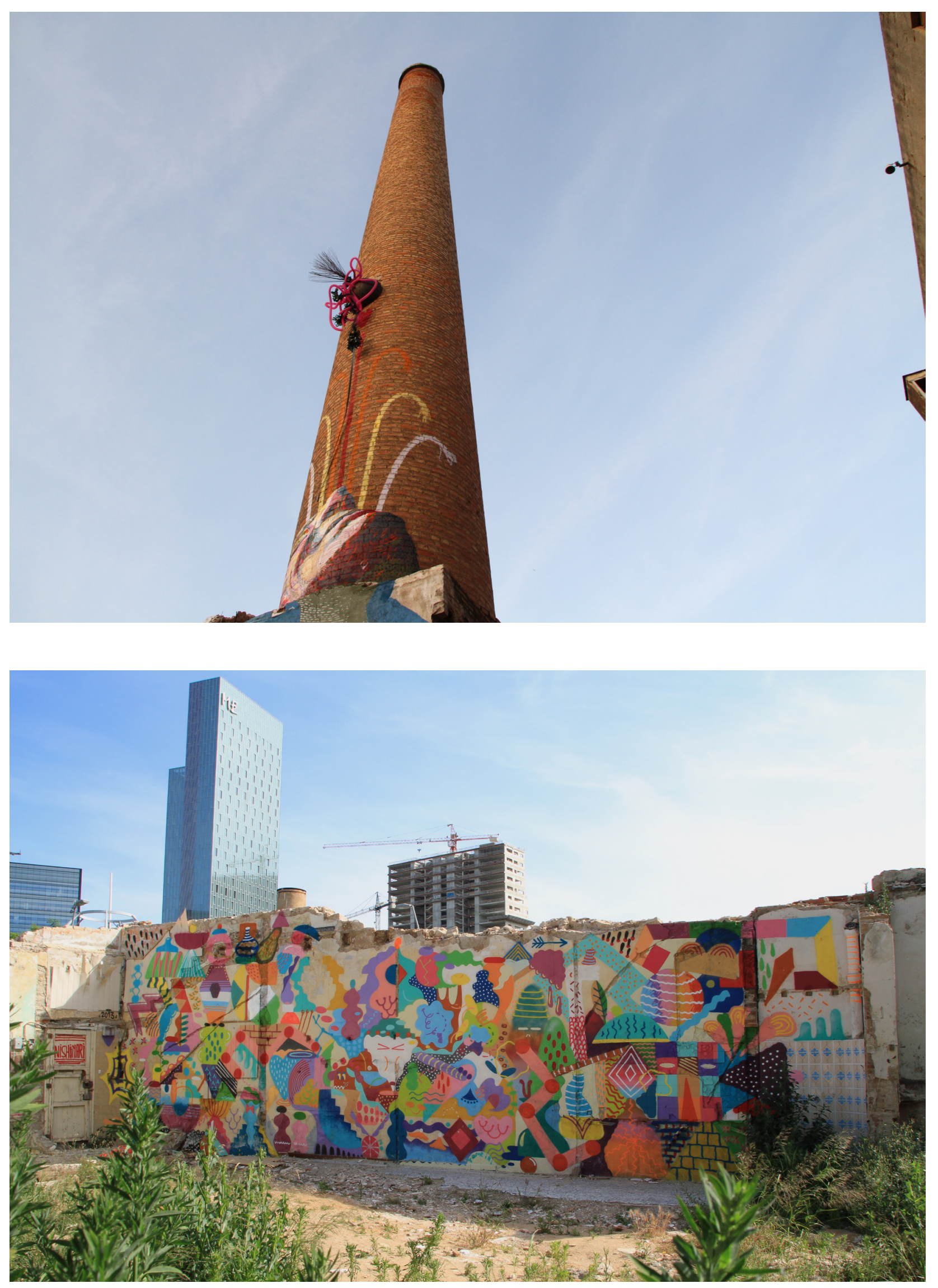

Top: Chimney in the patio of 'La Escocesa'

Bottom: Mural by Mina and Zosen 
Zosen added:

“...when we paint a mural on the streets, the limits and the results are always more unpredictable and open than when we paint in the studio on a canvas or at a festival on a wooden surface. I like to think about the history and the hidden stories that encircle the walls of the cities, the different architectures and its traces and layers left in the space over time...."

Using the example of the mural that he was painting in collaboration with Mina ${ }^{7}$, next to 'El Hangar', which is another art centre close to 'La Escocesa', he described his creative process as follows:

“...this wall was part of a house next to the 'Can Ricart' building, which has been demolished but where you still can see the form of the stairs on the wall and some tiles of an old bathroom or kitchen... we have intervened in one part of the wall and the other part we have left to breathe".

These different layers or stories on the surface walls do not exist, according to Zosen, in all cities but are what he is searching for in every city that he visits.

“...our artworks are ephemeral and we paint on surfaces, which have their own stories... we integrate and add our art-works to those stories. Graffiti in Barcelona was created spontaneously and we did not need any formal authorization from the council, something that in other cities of Europe was impossible. Here graffiti did not compete with the rest of the city landscape... it was obviously linked to urban speculation and the transformation of neighbourhoods in the city centre such as 'El Raval.' It created many 'no places' such as abandoned and demolished buildings. The people from Barcelona understood that rhythm of the city and took advantage of it. These circumstances helped us to create our own styles and identities as street artists."

In other of my encounters at 'La Escocesa', Kafre explained to me how his way of making graffiti had been transformed and adapted to different spaces, material surfaces, and situations over time.

“... It is not the same when I paint on the street walls, at a graffiti festival, collaborating with someone like Nacho (H101), or painting on a canvas". “... I don't do the same thing when I paint a wall in an abandoned factory as when I paint a canvas; in contrast I see people that do the same letters either on canvas or on the walls in the street. I don't understand people who paint letters on a canvas nor those who paint with very thin brushes and minimal details on a train... each situation offers different possibilities from my point of view".

He summarized his argument, saying that some graffiti artists have different visual languages, which are conditioned by the features of the space, the surface on which they paint and the context in which they are painting. Finally, Kafre concluded:

“...If you paint the same thing using different means of communication you are not saying anything new, you are repeating yourself".

The approach described by Kafre is counterintuitive and presents graffiti as a practice that is not only spontaneous but also developed in different directions.

\section{Dialogues between anthropologists and graffiti writers}

Following on from the conservation with Kafre, we were in the studio at 'La Escocesa' with three more artists: Tom14, Kenor, and H101. I decided to share with them some of the case studies, ethnographic works, and theoretical concepts that I was using in my research to think about the city space and the conceptions and transformations of art within different contexts. My initial idea was to compare my examples with their conceptions of graffiti and street art in Barcelona. Firstly, I introduced them to the analysis by Fred Myers

7 http://cargocollective.com/minahamada 
(2006) of different anthropological discourses in regard to Australian aboriginal acrylic paintings. In this context, I described how the production of Pintupi acrylic paintings derived from aboriginal ceremonial designs and rock paintings, associated with myths and performance of rituals. Today, I stated, they enclosed a plurality of meanings linked to cultural identity, a right of place and commodities in the art market.

I asked them if they saw any parallels between this rock painting and its processes of transformation with the graffiti and street art in Barcelona. Their answers were based more on practical aspects and on their ways of making graffiti and street art than on the meanings that their artworks could have within their community or society. They talked about dimensions, surfaces, textures, colours, atmospheres, spaces, tools, collaborations and means of communication and how they explored those elements of their artworks either individually or by engaging in collaborative relations with other artists. Kafre explained his experiences of when he started to paint collective murals:

“...when we painted with the ONG crew, there was a game partly motivated by me in which we tried to forget our own identities and create something new as a group. Here, it was very important to play with your own style and adapt it to the common idea. We studied the creation of the murals on the spot paying attention to everything that was happening around what we were painting. There were many variables that could play against a collective work; some of us painted with straight lines, others made circles and sometimes things did not work together".

At this point I asked Kafre if he thought that these collective murals that they made were linked to the tradition of collectivization and social movements in the city. He replied:

“...I don't think so, we were probably more inspired and influenced by the pioneer graffiti writers in the 1980s and 1990s who used to do collaborative murals as well. The only difference is that those pioneer graffiti artists divided the walls into sections and each of the participants painted their own section over a common background. They painted together but did not mix or change their styles. In the ONG crew that changed. There were not sections for each one of us: all of us painted on a single surface. I remember for example, when we started a figuration and someone said, I don't know how to resolve this problem of the weight of colours. So we asked someone else. Hey! Can you do something here? I know your style and I think you can resolve it. I do it... Like this was how we tried to resolve the problems that we faced throughout the process. You started to paint with an idea and then conflicts appeared: this figure is not right; it needs to be contrasted. Here there is a lot of weight of colours and there is not so much there. But we assigned problems to each of us and resolved them together. That was one of the nice things about painting together but in a serious way".

They also talked about the graffiti scene in the city and how it had marked their social relations and their development as individual artists. Kenor said:

“...before there were walls where we could paint freely and there were at least thirty people in the city who were very active in the streets and it helped to create a very vibrant scene in Barcelona that evolved every day. The city was in permanent transformation and that inspired the graffiti and street artists to paint and think together. You always wanted to paint more and more".

Zosen also critiqued how the local council nowadays persecuted local graffiti:

"The graffiti and street art scene does not exist in the streets anymore and the people who were part of that local movement feel pity about the situation that we are facing today".

In relation to this negative situation, Kafre saw something positive:

"...today the fact that we cannot freely paint in the streets makes us explore other alternatives as well. It has also contributed to a definition of more personal styles. Kenor, for example, like 

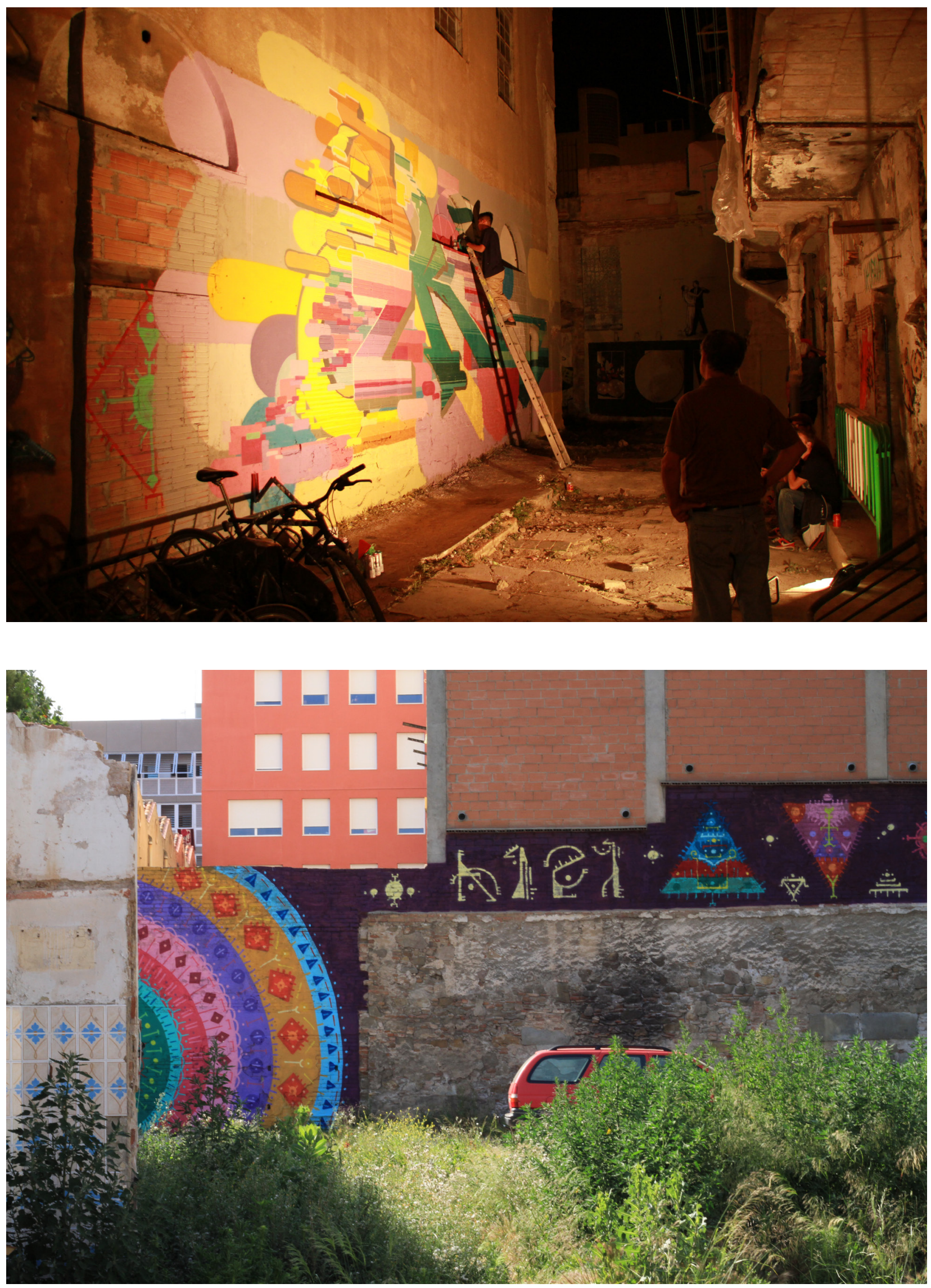

Top: Mural by ZKE One

Bottom: Mural by $\mathrm{HIOI}$ 
other graffiti artists, has moved into new realms where his graffiti artworks include sculptures or installations and have been represented through performances and the use of video".

\section{Mural by H101. Photo by Plácido Muñoz}

I also wanted to know in more detail about how graffiti artists interacted with the space to create their works. Thus, I shared with them an ethnographic study focused on the Western Apache community by the linguistic anthropologist Keith Basso (1984). In this work, Basso used the concept of 'chronotope' to approach the relationship between Western Apache's stories and places. Drawing on Basso, I see graffiti artworks in public space as 'chronotopes' that enclose stories and memories that make the city's everyday 'time take on flesh' (Bakhtin 1981:84, as cited by Basso 1984:44-45). Like the Western Apache storytellers, I tried in this case to use the urban landscape features marked by graffiti artworks to transmit an insight into life in Barcelona and its transformation over time. The relationship between graffiti and street artists and the features of the urban landscape were not only about telling stories through their artworks but also about making them.

It could be argued that the space and its features were also tools as instrumental as the spray paint colours and brushes, which were chosen by the artists to materialize, encode and transmit meanings. As the graffiti artist H101 explained, the material features of the buildings that form the art centre of 'La Escocesa' and its surroundings provided them with inspiration and spaces to develop their artworks. Trying to understand this relationship between graffiti artists and space, I asked Kafre how he selected the space to create his works? Kafre told me:

“... I don't search for publicity through my works because that would not be very consistent with what I do... if what I do has this intimist and occultist atmosphere that I want to transmit through my works, I think that to make it very visible would go against its essence. So, I prefer to see my work more in the shadow and more hidden. It is only for those who really want to see the work without imposition... I can understand the repetition of other artists all over the city but that it is not my intention. In this scenario, the space is a key element in my artworks and they make sense and are accepted only in specific locations".

The space and its features become part of his visual language and this is materialized through specific colours such as gold and black and the application of particular techniques such as the scratching and burning of walls. As he put it,

“...my goal is the creation of dark atmospheres shaped by mythological and supernatural creatures that can enclose secret languages, prophecies or other stories. For me, searching for locations for my interventions is very simple. What I need, is a wall painted with lime that I can scratch on, you don't find these kinds of walls so easily. Either it is a wall of an abandoned house or it could be also a wall left after a building has been demolished... those are my favourite surfaces and places".

The way in which the work of Kafre had evolved had been shaped by both his own personal interests and the difficulties of painting on open walls in the city. In general terms, the transformation of graffiti in Barcelona affected the way of making graffiti, restricting the spontaneity, anonymity and freedom of the artists. Thus, the spontaneity of the graffiti interventions was transformed into something more planned and precise as we have appreciated in the case of Kafre. The development of more elaborate techniques also transforms the spontaneous features of graffiti actions from something occasional (Silva 1987) into something more regular. The Escocesa's Mural Festival is another exponent of how the graffiti and street art scene has evolved in the city. Here, the local and resident graffiti and street artists in 'La Escocesa' are the main organizers, participants, and curators. The festival offers the space and time, and also the logistics, for graffiti and street artists to develop their artworks on different surfaces and on a large scale. The duration of the festivals was five days, during which the invited artists painted their murals on the outside walls of 'La Escocesa'. They also organized live painting, the screening of documentaries, music performances, conferences, and debates. The crowd who assisted at the 'Festivals' could move around freely within the space of 'La Escocesa', talk with some of the artists, have something to eat or drink, observe and take photographs of the outdoor murals, or see a photographic exhibition displayed in one of the rooms of the main building. 


\section{Conclusion}

I approached 'La Escocesa' as a laboratory of graffiti and street art in Barcelona, where the resident graffiti artists experimented with new textures, scales and spaces, evolving and adapting their artworks to the new situation in the city and fostering collaborations between them and other artists. My methodological experiment of sharing with the participants some of the case studies that I had thought analogous to the graffiti in Barcelona, did not lead to clear answers, but rather complex relations. This made me think about the role of the ethnographers and the different ways of seeing and questioning reality. On the other hand, the answers of the participants also revealed questions about the ways in which ethnographers produce knowledge, opening up new ways of looking at it throughout the fieldwork. The practice of graffiti in Barcelona enclosed a certain way of being in the city, which was exposed more than in the production of art or non-art objects, in the creation of social and material relations and experiences between them and with the inhabitants of the city. Throughout my fieldwork, I realized that one of the key pillars in their subsistence and development, as graffiti artists, was how they collaborated with and engaged in the act of creation with their self-managed projects. In this context, the resident graffiti artists in 'La Escocesa' have created their own channels and space in which to create and display their works. The organization of the graffiti Festival in 'La Escocesa' and their personal approaches to creativity were examples of their own way of making graffiti and street art in the city. 


\section{References}

Basso, K (1996) 'Wisdom sit in places: notes on the Western Apache landscape'. Pp. 53-90 in S. Feld and K. H Basso (ed.) Senses of Place. Santa Fe, NM: School of American Research press.

Bakhtin, M.M. (1981) The Dialogic Imagination: Four Essays by M.M Bakhtin, in M. Holquist (eds), trans by C. Emerson \& M. Holquist. London: University of Texas Press.

Clifford, J. (1980) 'Fieldwork, Reciprocity and the Making of Ethnographic Texts: The Example of Maurice Leenhardt'. Man. 15(3): 518-32.

Degen, M. (2008) Sensing Cities: Regenerating public life in Barcelona and Manchester. London: Routledge

Myers, F. (2006) 'Representing Culture: The production of discourses for Aboriginal Acrylic Paintings'. Pp.495-519. in Perkins and Morphy (ed.) The Anthropology of Art. London: Blackwell.

Page, E. H. (1988) 'Dialogic principle of interactive learning in the ethnographic relationship'. Journal of anthropological research. 44(2): 163-181.

Rama, A. (1996) The Lettered City, translated by John Charles Chasteen. London: Duke University Press.

Schacter, R. (2013) The world atlas of street art and graffiti. London: Yale University Press.

Silva, A. (1987) Punto de vista ciudadano: focalización visual u puesta en escena del graffiti. Bogotá: Publicaciones del Instituto Caro y Cuervo: Series Minor XXIX.

Strohm, K. (2012) 'When anthropology meets cotemporary art: Notes for a politics of collaboration'. Collaborative anthropologies. 5: 98-124.

Zukin, S. (2009) Naked City: The Death and Life of Authentic Urban Places. London: Oxford University Press.

\section{Acknowledgments}

'La Escocesa' art centre and Zosen, Kafre, H101, Tom14 and Kenor. 